QIJIS: Qudus International Journal of Islamic Studies

Volume 6, Issue 1, February 2018

\title{
LIFE AND WORKS OF DR. MUHAMMAD HAMIDULLAH: AN OVERVIEW
}

\author{
Samee-Ullah Bhat \\ Shah-i-Hamadan Institute of Islamic Studies University of Kashmir \\ bhatsamiullah121@gmail.com
}

\begin{abstract}
Dr. Muhammad Hamidullah was a prolific author whose imposing life in the field of writing was characteristically distinguished from other personalities and who devoted his life to religious and academic works and inspired many scholars for serving the cause of Islam. In modern times, it is also surprising enough for every scholar who observes the circumstances in which Dr. Hamidullah lived on one hand and the large number of valuable works produced by him about different subjects on the other hand with high academic standards. He has almost covered the whole range of Islamic studies in his writings and tried to explore true picture of Islam and its fundamental sciences. Although the dimensions of his works spread over all these spheres- theology, the holy Qur'an, Hadith, Fiqh, Islamic History and culture, ethics, politics, economics but hadith, Fiqh, Sirah and Islamic History were his favorite subjects. His contributions to these subjects were universally recognized in academic circles from the point of richness of material and high standard of research. In this research paper, an attempt is made to illustrate the life of Dr. Muhammad Hamidullah in a brief manner on one hand and an analysis of his major works on Sirah has been discussed on the other hand.
\end{abstract}


Keywords: Life, Works, Sirat Ibn Ishaq, and Battlefields of the Prophet

\section{A. Introduction}

Dr. Muhammad Hamidullah was one of those towering scholars of the Indo-Pak subcontinent who left great impact on the Muslim world through his significant contributions to the fundamental sciences of Islam and sincere services to the society at large. Although, he belonged to Hyderabad (A P, India) but he passed major parts of his life in Paris occupying himself with delivering lectures and writing books on the important aspects of the Islamic sciences (Qur'an, Hadith, and Fiqh). It goes to his credit that he had command on different well-known languages of the world including Arabic, Persian, Urdu, English, and French and was also familiar with Turkish, Russian, Latin and German languages. In the field of Islamic history and Sirah, his works are mainly related to the Sirah of Prophet Muhammad (SAW) in French, English and Urdu. The significant contribution of Dr. Hamidullah to Sirah literature is that he has written on such aspects of Sirah which were not touched by other scholars. With regard to the Sirah literature another significant contribution was collection and compilation of the documents of the times of Prophet (SAW) which included the text of his letters and that of his agreements with the people of Makkah and different tribes of Madinah and adjoining areas. In this research paper, an attempt has been made to describe an overview of his life and major works on Sirah of the Prophet Muhammad (SAW) in an analytical way.

\section{B. Discussion}

\section{Life of Dr. Muhammad Hamidullah: A Brief Overview}

Dr. Muhammad Hamidullah was born in an illustrious family of scholars, jurists, writers and Sufis. His father, Mufti Abu Muhammad Khalilullah, was a scholar of considerable accomplishments. He migrated from Madras to Hyderabad where he was appointed director of the revenue Department and set 
up the first non-interest financial institution and passed away in 1943 C.E. (Momin, 2006: 21).

Dr. Hamidullah was born in 1908 CE in Hyderabad. He was the youngest among the three brothers and five sisters, who were all well versed in Arabic, Persian and Urdu, as well as in Islamic learning. He received his early education at home, first from his sisters and then from his father. Later he was admitted in the Madrasah Nizamiyyah where he passed the examination of molvi Kamil with distinction in 1924 C.E. His father had misgivings about Western education. Aware of his father's antipathy towards English education, the young Hamidullah secretively sat for the matriculation examination and, when the results were declared, topped the list of successful candidates. His father, who came to know about his son's dazzling success through the local newspaper, sent for him. The young scholar came to the father with trepidation, fearing that he would get a reprimand for having appeared for an English examination and that too without the father's permission. However, the young Hamidullah got a pleasant surprise when, instead of scolding, his father expressed his whole-hearted appreciation and joy over his son's achievement and told him to carry on with his education. His father's affection and encouragement kept him in good stead in the years to come.

Dr. Hamidullah joined Osmania University as a student in 1924 C.E and passed the B.A. in 1928 CE and LL.B and M.A. examinations with the first division in $1930 \mathrm{CE}$. He was awarded a fellowship by the Osmania University to pursue doctoral studies in International Islamic law. When he studied the material available in the libraries of Hyderabad, he was allowed to proceed abroad to study in libraries of Hijaz, Syria, Palestine, Egypt and Turkey. In Egypt, he met some Orientalists from Bonn University who invited him to get his doctorate from Bonn, Germany. Finally, he was permitted by Osmania University, for which he was preparing his thesis, to proceed to Bonn and submit the same thesis for a doctorate. He did it in August 1933 CE after completing only two terms (nine months) in the University. There, he selected only 
the last part of the work, dealing with the neutrality, to print and get the degree. The topic of his thesis was Die Neutralitat im Islamischen Volkerrecht (Neutrality in Islamic International Law).

After spending some time in Germany, he came to Paris in 1934 where he registered at the Sorbonne University for another doctoral degree on an allied subject "Early Muslim Diplomacy". In a short period of eleven months, Sorbonne University conferred on him the degree of D. Litt. The full title of his dissertation is La diplomatie musulmane a I'epoque du Prophete et des Khalifes Orthodoxe (Muslim diplomacy in the time of the Prophet of Islam and his orthodox successors).

In recognition of his outstanding ability and proficiency in several oriental languages, he was appointed a lecturer in Arabic and Urdu at Bonn University (http://www.renaissance.com.pk/ Febobti2y4.html). Before his stay in Europe, Hamidullah had an opportunity to visit Istanbul. He visited the famous libraries and museums of Istanbul and saw thousands of rare Islamic manuscripts in Arabic, Persian and Turkish languages.

In $1985 \mathrm{CE}$, he was awarded Hilal-e-Imtiaz, the highest civilian award of Pakistan as a token of appreciation for his outstanding services to the cause of Islam. The award included a substantial monetary amount. But he donated the whole award money to Islamic Research Academy, International Islamic University, Islamabad, in recognition of which the Institute named its library after Dr. Muhammad Hamidullah. He was nominated for the prestigious King Faisal Award, but he declined it saying that "he feared that if he were to accept any worldly reward for his modest work, he may not get his due in the hereafter and be left with only his sins in his book of deeds and, therefore, 'I keep telling everyone I don't want these awards" (Ahmad, 2003: 20). Dr. Hamidullah's selflessness and complete detachment from worldly allurement was reminiscent of the example set by the Muslim scholars and sages of earlier times. 


\section{Works of Dr. Muhammad Hamidullah on Sirah: An Overview}

Dr. Muhammad Hamidullah was a prolific writer and his works may be considered as encyclopedic ones. As a dedicated researcher and great Islamic scholar, he contributed to all the major branches of the Islamic sciences particularly Qur'an, Hadith, Islamic jurisprudence and Sirah in different languages. He is one of those eminent scholars of the modern period who had left very deep impact on the academic life of the Muslims of the entire world. His writings covered major subjects of Islamic studies including al-Qur'an, Hadith, Islamic jurisprudence, Sirah of the Prophet Muhammad (SAW), history of the formative period of Islam and International law of Islam. His works are also considered very important from the point of view of their high standard of research and rich material about the subject concerned. His works are based mainly on the original sources. While utilizing the sources, he did not simply borrow material from them but also adopted critical attitude towards them. It also goes to the credit of Dr. Hamidullah that his works are not confined to any particular language. These are available in the well-known languages of the world such as Arabic, Urdu, Persian, and English, French and Turkish (Momin, 2003: 85). With regard to his works, what is more important to see is the value of their contents which shows his excellence in different subjects of Islamic studies and his command over the well-known languages of the world? It may be realized from the detailed study of his works and analysis of their contents. Here, we are only attempting at an overview of some of his main works related to Sirahof the Prophet (SAW).

\section{a. Sirah Ibn Ishaq}

Sirah Ibn Ishaq (Arabic) which has been edited by Dr. Hamidullah is a significant contribution to Sirah literature. This is actually a critical edition of one of the earliest Sirah works of the Prophet Muhammad (SAW) written by Ibn Ishaq (d. 151A.H/ 768C.E) (Faruqi, 2004: 147).It goes to the credit of Dr. Hamidullah 
that he discovered this important work on Sirah which was untraceable for about 13 centuries. Its manuscript was not available in complete form in any library. Two parts of the work were preserved in the Library of Maktabah Quruyain, Fas (Fez) and one was available in Zahiriyyah Library of Damascus. Dr. Muhammad Hamidullah closely scrutinized these three parts of the manuscript and prepared its critical edition under the title "Sirah Ibn Ishaq Mussamah ba Kitab al-Mubtada wal-Mab'ath wal Maghazi"(Zafarullah, 2004: 77-79). In the introduction of the work, the learned editor has given many important issues including Arabs' concept of historiography in pre and post-Islamic period, origin of the Sirah writing, early Sirah literature and life and works of Ibn Ishaq (Hamidullah, 2001: 357-392). This is also a notable work of Dr. Hamidullah on Sirah that he critically studied Sirah Ibn Hisham and brought out weak aspects of this book. According to him, Ibn Hisham has not given all riwayat of Ibn Ishaq. Dr. Hamidullah not only pinpointed them but also recorded them in the edition of Sirah Ibn Ishaq. He also stated that Ibn Hisham quoted the traditions given by Ibn Ishaq on the authority of Ziyad Ibn Bakkai (d.183 A.H. / 799 C.E.). But, no narrator of this name is referred to in the manuscripts of Maktabah Quruyain (Fas) and Zahiriyyah Library (Damascus) (Hamidullah, 2001: 388).

The work was first published from Ma'ahad al-Darasai wal-Abhath lil-Tadib (Rabat) in 1976(Zafarullah, 2004: 77-79). Its Urdu translation by Nur-i-llahi was first published in second volume of the Nuqush Rasul (SAW) Number (a quarterly Journal of Lahore) in Jan. 1985. The work was also published in the book form from Milli Publications (Delhi) in 2000 and Centre Culturel Islamique (Hyderabad) in2001 (Faruqi, 2004: 147).

\section{b. Muhammad Rasūlullah (SAAS)}

Muhammad Rasūlullah (SAAS) of Dr. Hamidullah is an important English work on Sirah of the Prophet Muhammad (SAW) and is quite useful for common readers. The special feature of the book is the objective and realistic approach of the author towards various aspects of the Prophet's life. For instance, it was 
generally held by the Western as well as some Eastern scholars that the Prophet (SAW) was born on Monday 20 April, 571 C.E., while Dr. Muhammad Hamidullah considers Monday, June 569 as the actual date of his birth (Hamidullah, 1974: 1). Besides, it is generally held that Hadhrat Khadija (R.A) was forty years old at the time of her marriage with the Prophet Muhammad (SAW). But, Dr. Hamidullah is of the opinion that Hadhrat Khadija (RA) was 28 year old at that time. This shows a difference of only three years between the respective ages of husband and wife. In support of his standpoint, he stated: "This latter report seems to be corroborated by the biological facts that she gave birth to seven children, three sons and four daughters after her marriage with the Prophet (SAW): Taiyib, Qasim, Tahir, Zainab, Ruqaiyah, Umm-e-Kulthum and Fatimah" (Hamidullah, 1974: 9).

In addition to the above, the Ascension(Mi'raj) of the Prophet (SAW)is believed to be physical by a majority of Muslims. Dr. Hamidullah said: Let us not envisage it (Ascension) as a touristic affair, but of spiritual import". He argues that the Qur'an itself has used the word ru'ya, a vision for this event. And the Prophet (SAW) says "It happened while 1 was in a state between sleep and wakefulness" (Hamidullah, 1974: 18). Further, according to Dr. Hamidullah this experience had been enjoyed by Enoch (Idris), Abraham (Ibrahim), Jacob (Yaqub), and several other Prophets too (Hamidullah, 1974: 52). Moreover many other new facts discovered and presented by Dr. Hamidullah in the book are different from the views of other scholars.

The work was published from various places including Centre Culturel Islamique (Paris), Habib and Company (Hyderabad) in 1974, and Hazafah Publication (Karachi) in 1979. It was translated into Urdu by Nazir Huq, former chief editor of Mashriq (Lahore), and published in Rasul Number of the reputed Urdu, Journal Nuqush (Karachi) in Vol. 2, 1982 (Hamidullah, 1974: 52). 


\section{c. The Battlefields of Prophet Muhammad}

The Battlefields of the Prophet Muhammad (English) of Dr. Hamidullah was written for the first time in French language under the title Le Champs de Bataille an Temp dii Prophet and was published from Revue Des Etudes Islamiques (Paris) in 1939. The author himself produced English version under the title The Battlefields of the Prophet Muhammad and got it published in Islamic Review (London) during 1952-53. The work was published separately in the book form from different places in India and Pakistan including Centre Culturel Islamique (Hyderabad, 1959, 1973, 1983) and Zaifah Publications (Lahore, 1979). The Urdu version 'Ahd-e-Nabawi ke Maiddn-e-Jang prepared by author himself and was published for the first time in Majmu'ah Tahqiqat-e-'Ilmiyah, the Urdu Journal of Osmania University (Hyderabad) in 1940. In 1945, it was published as a separate book from Intezamiyah Press (Hyderabad). The book became so much popular in the academic circle that it was translated into several languages including Arabic, Persian, Turkish, Malayalam and Sindhi. The work is divided into nine Chapters' namely (Hamidullah, 1973: 3):

1. Preliminary Remarks

2. Badr

3. Uhud

4. Battle of Ditch

5. The Conquest of Makkah

6. The Battle of Hunain and Taif

7. Wars with Jews

8. Military Intelligence in the Time of Prophet Muhammad (SAW)

9. Military Department of the Muslim State in the Time of the Prophet Muhammad (SAW)

In this book Dr. Muhammad Hamidullah discussed the life of Prophet (SAW) as a Commander-in-Chief of the Muslim army. He did not follow the traditional method to show that the battles were conquered merely by miracles. He presents a detailed 
comprehensive study of Prophet's strategies and achievements in the battlefields. In the introduction of the book he writes (Hamidullah, 1973: 1):

"1 never refer to the miracles of the Prophet Muhammad (SAAS) in my description of his "great exploits". My humble reply is that I am dealing with a general and comprehensive life of the messenger of Islam in order to discuss this point. If he had achieved his success by miracles only, his life could not be an Uswah Hasanah, a practical example to be followed by the common man, which it was according to the Qur'an. Unless this human aspect of cause and effect is put before the common man- who does not and cannot rely on miracles, but has to help himself in the struggle of existence- he will not find the conduct of the Prophet Muhammad (SAW) a worthy and a practicable example to imitate".

The most important aspect of the work is that it was written on the basis of authentic sources of Islamic history including Sirah Ibn Ishaq, Sirah Ibn Hisham, Tarikh al-Tabari, Tafsir al- Tabari, Tabaqat Ibn Sa'd, Wafa al-Wafa Li al-Samhudi, Maghazi al-Waqidi etc(Hamidullah, n.d.: 57-58). Dr. Hamidullah also visited Madinah, Makkah and Taif in 1932 and 1939 to determine the locations of various battlefields. He measured the exact locations of these battlefields in the light of the data preserved in the early Islamic texts and prepared maps and graphs. The work also highlighted the political and diplomatic background of the various battles and examined their impact.

\section{Conclusion}

From the above discussion, it can be concluded that Dr. Muhammad Hamidullah was one of those eminent scholars of the Indo-Pak subcontinent of the modern times who is well known for his prominent contributions all over the world. It goes to the credit of Dr. Muhammad Hamidullah that he has left more than 150 published books and thousands of research papers and articles in different languages. Dr. Hamidullah, a leading and distinguished figure of contemporary times devoted his works to Sirah and Islamic history. His edited manuscript of Sirah Ibn Ishaq is an outstanding contribution to make the classical Sirah 
works easily available. Many of his other prominent works are even on Sirah which are written with comprehension and on the basis of primary sources and most of his writings on history mark the distinction of authenticity of sources, exactness and lucidity of style.Some of the modern scholars have highlighted the significance of the work so much that they compared his academic contribution with that of Abu Nasr al-Farabi, Abu Hamid al-Ghazali and Shah Waliullah Dehlawi. 


\section{REFERENCES}

Faruqi, Lutfur Rahman. 2004. Dr. Muhammad Hamidullah Ki Chand Mashur Kutub-e-Sirat Ka Ta'aruf Aur Unke Mundarjat", Ma'arif -e-Islami (Islamabad), Vol. 2-3, No. 2-1, July, 2003June 2004.

Hamidullah, Muhammad. 2001. Sirah Ibn Ishaq.Hyderabad: Centre Culturel Islamique.

2010. Muhammad Rasulullah (SAW). Mili Publications.

.1986. The Prophet's Establishing a State and His Succession. Hyderabad: Habib and Company.

. 1973. The Battlefields of the Prophet Muhammad. Hyderabad: Habib and Company.

n.d.Ahd-e-Nabawi ke Maidan-e-Jang. Hyderabad: Intezamiyah Press.

. 1987.Rasul-e-Akram (SAW) Ki Siyasi Zindagi. Karachi: Dar al- Isha-at.

. 1968. Introduction to Islam, 3rd ed. Lahore: Sh. Muhammad Ashraf.

. 2007.The Prophet's establishing a state and his succession, New Delhi: Adam Publishers, (the Hyderabad Deccan print 1406/1986).

. 1989.Le Prophete de l'Islam (French), Tome II, Assocition des Etudiants Islamique en France, Paris.

. 1941. al-Watha'iq al-Siyasiyah, Beirut.

. 1974. Muhammad Rasulullah, Paris: Centre Culturel Islamique.

Momin, Abdur Rehman. 2006.Dr. Muhammad Hamidullah, Sirat, Kamalaat Aur Ifadaat. Farid Book Dept. Pvt. Ltd. 
— 2003.Professor Dr. Muhammad Hamidullah.Islamic Culture (Hyderabad), Vol. 77, No. 4, Oct.

Zafarullah, Khalid. 2004. Dr. Muhammad Hamidullah Ki Khidmate-Hadith". Ma'arif-e- Islami (Islamabad), Vol. 2, 3, No. 2-1, July 2003-June, 2004.

http://www.renaissance.com.pk/Febobti2y4.html Accessed on 25-5-2008 